\title{
Endoscopic Lung Volume Reduction: An Expert Panel Recommendation
}

\author{
Felix J.F. Herth ${ }^{b}$ Dirk-Jan Slebos ${ }^{a} \quad K^{\prime}$ laus F. Rabe ${ }^{c, d}$ Pallav L. Shahe, $f$ \\ ${ }^{a}$ Department of Pulmonary Diseases, University Medical Center, University of Groningen, Groningen, \\ The Netherlands; ${ }^{b}$ Department of Pneumology and Critical Care Medicine, Thoraxklinik, Translational Lung \\ Research Center Heidelberg, University of Heidelberg, Heidelberg, ' $L$ LungenClinic Grosshansdorf and Airway \\ Research Center North (ARCN), Grosshansdorf, and 'Department of Medicine, Christian-Albrechts-Universität \\ zu Kiel, Kiel, Germany; ${ }^{\mathrm{e}}$ The National Institute for Health Research Respiratory Biomedical Research Unit, Royal \\ Brompton, Harefield NHS Foundation Trust and Imperial College, and ${ }^{\mathrm{f}} \mathrm{Chelsea}$ and Westminster Hospital, \\ London, UK
}

\section{Key Words}

Chronic obstructive pulmonary disease $\cdot$ Emphysema .

Bronchoscopy · Lung volume reduction · Expert statement

\begin{abstract}
Chronic obstructive pulmonary disease (COPD) is a progressive condition comprising a constellation of disorders from chronic bronchitis, airflow obstruction through to emphysema. The global burden of COPD is estimated at more than $6 \%$ of the population. The standard of care is based on a combination of smoking cessation, immunization, pharmacological treatments and pulmonary rehabilitation. However, the more advanced stages of COPD are challenging to manage. In this situation, our current standards of care do not adequately control patient symptoms nor halt the progressive decline. For the emphysema phenotype, lung volume reduction surgery has shown a beneficial effect in selected patients but is counterbalanced by the morbidity experienced by some patients. Bronchoscopic volume reduction technologies have been developed to improve the clinical situation of emphysema patients. This expert statement provides broad guidance regarding patient selection and the current position of the available techniques for patients with advanced emphysema.

(c) 2016 S. Karger AG, Basel
\end{abstract}

\section{Introduction}

Chronic obstructive pulmonary disease (COPD) is a chronic disease of the lungs. The classical symptoms of COPD are shortness of breath, excessive production of sputum, and chronic cough [1]. COPD is progressive and ultimately a life-threatening disorder. Treatment can slow its progression, but it cannot be cured. The emphysema subgroup is characterized by progressive alveolar damage and loss of alveolar structure, particularly alveolar tetherings [2]. The net effect is reduced surface area for gas exchange but also pressure-dependent airway collapse. The physiology is characterized by both static and dynamic hyperinflation [3].

Accurately estimating the prevalence of COPD is difficult due to widely varying diagnostic criteria, varying methods and different reporting rates, e.g. from patients versus diagnosticians. These and other factors may lead to widespread underreporting of COPD [4].

In a systematic review and meta-analysis, the pooled prevalence estimate for COPD was 7.6\%, including studies reporting combined chronic bronchitis and emphysema [5]. The burden of the disease results in an estimated economic cost of USD 2.1 trillion for 2010, and USD 4.8 trillion for 2030 [6].

\section{KARGER}

E-Mail karger@karger.com

www.karger.com/res
C) 2016 S. Karger AG, Basel

0025-7931/16/0913-0241\$39.50/0
Univ.-Prof. Felix J.F. Herth, MD, PhD, Dsc, FCCP, FERS Department of Pneumology and Critical Care Medicine Thoraxklinik, University of Heidelberg Röntgenstrasse 1, DE-69126 Heidelberg (Germany) E-Mail felix.herth@med.uni-heidelberg.de 
Table 1. Baseline characteristics of the endoscopic lung volume reduction trials compared to the initial NETT trial inclusion criteria

\begin{tabular}{|c|c|c|c|c|c|c|}
\hline Inclusion criteria & NETT & EBV/VENT & IBV & Coils & Bio-LVR & BTVA \\
\hline Age, years & $40-74$ & 63 & 65 & 60 & 64 & 63 \\
\hline Emphysema location & All & UL/LL & UL/LL & UL/LL & UL & UL \\
\hline $\mathrm{FEV}_{1}, \%$ predicted & $20-45$ & 30 & 31 & 29 & 31 & 31 \\
\hline RV, \% predicted & $>150$ & 216 & 221 & 238 & 238 & 237 \\
\hline $\mathrm{PaO}_{2}, \mathrm{~mm} \mathrm{Hg}$ & $>45$ & 69 & 68 & 64 & 65 & 64 \\
\hline $\mathrm{PaCO}_{2}, \mathrm{~mm} \mathrm{Hg}$ & $<50$ & 41 & 41 & 42 & 41 & 40 \\
\hline 6MWT distance, $\mathrm{m}$ & $>140$ & 333 & 337 & 306 & 293 & 300 \\
\hline
\end{tabular}

Bio-LVR = Biological lung volume reduction (Aeriseal).

Risk factors for COPD are tobacco smoking and occupational or environmental exposure to particulates or harmful gases. Smoking cessation may be accomplished through patient education and counselling. The medical standard of care for treatment of COPD consists of treatment with one or more bronchodilators, including $\mathrm{B}_{2}$ agonists and anticholinergic agents. All bronchodilator drugs commonly used to treat stable COPD have been shown to improve symptoms and to reduce the number and duration of exacerbations [7].

COPD is a progressive disease with around half of the severe-stage patients developing severe hyperinflation [8]. In 1957, Brantigan and Mueller [9] performed the first lung volume reduction surgery (LVRS) procedure, in which tissue from one or both lungs is resected in order to treat the physiological consequences of emphysema. Despite the good long-term data in highly selected patients, LVRS is associated with significant mortality and morbidity, especially in high-risk patients.

Despite the demonstrated efficacy in the National Emphysema Treatment Trial (NETT) more than 10 years ago, LVRS is extremely scarcely used. Illustrative of this is the Medicare reported number of 93, 65 and 42 LVRS procedures performed in the USA in the years 2011-2013 [10]. Also the number of post-NETT LVRS published original scientific trial papers is very scarce. A number of new technical changes have been proposed to reduce adverse events, but hardly investigated and only reported as case series and a single RCT. Two interesting techniques, which should be further investigated, involve unilateral lobe resection by video-assisted thoracoscopic surgery [11] and nonresectional LVRS, which entails plication of the most severely emphysematous target areas [12].

LVRS candidates are biological lung volume reduction candidates and vice versa (table 1), and the dramatic im- provements observed with LVRS in well-selected patients, combined with the need for less invasive options for surgically unfit emphysema patients have stimulated the development of endoscopic lung volume reduction $[13,14]$.

\section{Patient Selection}

Potential evaluable patients for advanced emphysema treatments are those who are already receiving the best medical treatment, i.e. optimal pharmacological therapy mostly with bronchodilators, inhaled corticosteroids, and sometimes maintenance systemic therapies. Patients should also have completed pulmonary rehabilitation and/or are participating in a structured physical therapy program, and have definitely stopped smoking. The key evaluations include a full medical assessment, lung function measurements, CT scan of the thorax, and the 6-minute walk test (6MWT). Based on the available data, patients with severe airflow obstruction [i.e. GOLD stage $3 / 4$ (C/D), $\mathrm{FEV}_{1} 20-45 \%$ ], hyperinflation (RV $>175 \%$ or $\mathrm{RV} / \mathrm{TLC}>0.58)$, and a reduced 6MWT $(100-500 \mathrm{~m})$ may be considered for lung volume reduction therapies. Patients with severe pulmonary hypertension (right ventricular systolic pressure measured by echocardiography $>50$ $\mathrm{mm} \mathrm{Hg}$ ) and significant comorbidities, which cannot be corrected, should be excluded (table 2).

\section{Radiological Assessment}

Standardized CT scans are required to characterize the emphysema, evaluate the distribution of the emphysema destruction and determine the integrity of the lobar 
Table 2. Main inclusion and exclusion criteria for lung volume reduction therapies

\begin{tabular}{ll}
\hline Inclusion & Exclusion \\
\hline COPD - emphysema phenotype & Clinically significant bronchiectasis \\
$\mathrm{FEV}_{1} 20-45 \%$ of predicted & Previous lung surgery: lobectomy, pneumonectomy, lung transplantation \\
$\mathrm{RV}>175 \%$ of predicted & Severe hypercapnia $\left(\mathrm{PaCO}_{2}>8 \mathrm{kPa}\right.$ or $\left.60 \mathrm{~mm} \mathrm{Hg}\right)$ and/or hypoxia $\left(\mathrm{PaO}_{2}\right.$ \\
$\mathrm{RV} / \mathrm{TLC}>58 \%$ & $<6.0 \mathrm{kPa}$ or $45 \mathrm{~mm} \mathrm{Hg})$ both at room air at sea level \\
Optimal medical treatment & DLCO $<20 \%$ of predicted \\
Nonsmoking & Significant pulmonary hypertension: right ventricular systolic pressure $>50$ \\
Postrehabilitation & mm Hg on echocardiography \\
Symptomatic $(\mathrm{mMRC}>1)$ & Congestive heart failure (left ventricular ejection fraction $<40 \%)$ \\
$6 \mathrm{MWT}$ distance $100-500 \mathrm{~m}$ & Significant comorbidities significantly affecting performance and survival \\
& $\begin{array}{l}\text { Maintenance anticoagulation: coumarines, low-molecular-weight heparin, } \\
\text { clopidrogel or similar antiplatet agents, dabigatran or similar }\end{array}$ \\
\hline
\end{tabular}

fissures. The CT protocol should be a standardized noncontrast volume acquisition on a multidetector scanner platform with thin $(0.6-1.25 \mathrm{~mm})$ series with some overlap. The primary assessment should also ensure the absence of significant comorbidity or abnormalities that require further assessment. If there are unexpected findings like bronchiectasis, pulmonary nodules, suspected lung cancer, interstitial fibrosis or severe tracheobronchomalacia, then the patients should be evaluated and treated based on the underlying disease. It would be inappropriate to consider them for endoscopic lung volume reduction.

The pattern of emphysema observed on the CT scan can be described as follows:

- centrilobular emphysema (most common)

- panlobular emphysema

- paraseptal emphysema

- localized emphysema.

The centrilobular pattern affects the proximal respiratory bronchioles which are seen as focal lucencies measuring from hardly visible defects up to $10-20 \mathrm{~mm}$ in diameter, located centrally within the secondary pulmonary lobule. The changes often involve the upper lobes or the apical segments of the lower lobes. The panlobular form involves the whole of the secondary pulmonary lobule, or even bigger defects, and often affects the lower lobes and tends to lead to more homogeneous involvement. Paraseptal emphysema affects the peripheral parts of the secondary pulmonary lobule. It is typically adjacent to the pleural surfaces and leads to the formation of subpleural bullae, with most often very well preserved more central lung tissue. Focal areas of destruction of the alveolar tissue with preservation of other areas are best described as localized emphysema.

Endoscopic Lung Volume Reduction
Emphysema quantification on CT is usually expressed as the proportion of pixels of $<-910$ or -950 Hounsfield units (HU) [15]. The -910 HU density threshold is commonly used for thick-slice ( $>3 \mathrm{~mm})$ CT scans. This threshold yielded the best correlation between emphysema, as determined from resected lung tissue and $10-\mathrm{mm}$-thick slice CT measurements [16]. With the advent of multislice scanners, also using volumetric reconstructions, the density thresholds for emphysema for different scan settings have been reinvestigated [17]. The strongest correlation between the pathology of macroscopic and microscopic emphysema and CT measurements has been reported at a threshold of $-950 \mathrm{HU}$ in 1-mm noncontrast chest CT scans $[18,19]$. Several density thresholds have since been proposed for emphysema quantification, but for thin-slice volumetric chest CT scans, $-950 \mathrm{HU}$ is nowadays the most commonly used threshold.

Using emphysema quantification scores, a relative lobar difference of this measure is regarded as heterogeneity. This can be done by simple visual analysis, but more accurate results are produced using software systems. Heterogeneity is the relative or percentage difference in the emphysema scores between ipsilateral lobes. To date, no clear definition exists for heterogeneity. In most trials reported, a $>25 \%$ difference in the proportion of pixels of $<-910 \mathrm{HU}$ or a $>15 \%$ difference in the proportion of pixels of $<-950 \mathrm{HU}$ has been used.

Finally, fissure integrity should be assessed, since this will guide the choice of treatment, and is defined as the completeness of the fissure [more than $85 \%$ of the fissure present on thin-slice high-resolution computed tomography (HRCT)] on all three axes (sagittal, axial and coronal view). Once again, this is possible visually with large interobserver variability, but more sophisticated software 
analysis produces more consistent results [20]. Based on the opinion of the expert panel, such an option should be used if available.

\section{The Technologies}

For all technologies described in this paper, see also table 3 .

\section{Endobronchial Valves}

Used first in 2002 [21], the one-way endobronchial valve (EBV) therapy remains the best studied until now. Valve treatment is targeted to the most emphysematous destroyed lung lobe, which will need to be completely occluded by the valves. The one-way EBVs are placed bronchoscopically to occlude the emphysematous lobe. The goal is to create an atelectasis of the region of the lung similar to that achieved by LVRS, although with valves. The valves allow the air to be expelled during expiration but not to enter the lobe during inspiration, thus facilitating the creation of a full lobar atelectasis. At the moment, two different valves are commercially available, the EBV (Zephyr, Pulmonx Inc., Neuchâtel, Switzerland) and the intrabronchial valves (IBV; Olympus, Tokyo, Japan).

For the EBV systems, three larger RCTs have been published. Two of them were performed by the VENT study group $[22,23]$. The randomized trial with the IBV met its clinical end-point, but there was no difference in quality of life or pulmonary function parameters [24]. The treatment strategy was bilateral incomplete lobar exclusion. The trials with the Zephyr valves demonstrated that the treated group significantly improves compared to an untreated control group. However, the results were not clinically meaningful. A post hoc analysis revealed that patients with a complete interlobar fissure on the HRCT scan experienced the best outcome following EBV implantation. A complete fissure (in this post hoc analysis defined as $>90 \%$ completeness of the fissure) between target and adjacent lobes on HRCT was used as an indirect surrogate for no or negligible interlobar collateral ventilation [25].

In a recently published trial by Davey et al. [26], this hypothesis was confirmed in a randomized, sham-controlled trial. In this study, unilateral lobar occlusion with EBV in patients with heterogeneous emphysema and intact interlobar fissures assessed on CT produces significant improvements in lung function as well as improvements in the quality of life. Therefore, a pretreatment fis- sure analysis must be performed, and patients with an incomplete fissure should not be considered for treatment with valves. The exact completeness of the lobar fissure necessary for an effective treatment is not well known. But there is a strong correlation between fissure completeness and valve treatment effect as measured by the occurrence of the desired lobar atelectasis, or by the measurement of actual collateral ventilation. The current data indicate that if the interlobar fissure between the treatment target lobe and adjacent lobe is less than $85 \%$ intact, proceeding to valve treatment is not useful because of the high likelihood of present collateral flow. On the other hand, if the fissure is between 95 and 100\% complete on $\mathrm{CT}$, there will be a very low occurrence of significant collateral flow [27].

To assess interlobar collateral flow, dedicated endoscopic measurement of the collateral flow is possible with the Chartis Pulmonary Assessment system (Pulmonx). Whether a patient is a candidate can be decided using bronchoscopy [28]. In a multicenter European study, it was shown that the fissure analysis and the endoscopic measurement have a high correlation [29].

Recently, Klooster [30] published the first results of STELVIO, an RCT, in which the best responder criteria to EBV treatment were evaluated using the measurement with the Chartis system as the primary treatment assessment tool. In this trial, 84 patients with $>90 \%$ complete fissures on CT were recruited, of whom 13 still showed presence of collateral flow. Intention-to-treat analyses at 6 months showed significant $(\mathrm{p}<0.01)$ between-group differences in favor of the EBV group which showed a change of $\mathrm{FEV}_{1}+140 \mathrm{ml}(95 \% \mathrm{CI} ; 55-225)$, FVC $347 \mathrm{ml}$ (95\% CI; 107-588) and 6MWT distance $+74 \mathrm{~m}(95 \% \mathrm{CI}$; 47-100), with an overall clinical significant responder rate to the treatment of $75 \%$.

Combing CT analysis with fissure assessment is even more important since several studies showed the low correlations between the fissure analyses by various - even expert - readers, except for bigger gaps of more than $30 \%$ [20]. To illustrate this: in the study by Davey et al. [26], there were 4 patients who were found to have collateral ventilation as measured by Chartis despite an intact fissure, and these patients had no clinical improvement and did not develop atelectasis.

When taking all these trials together, evidence is accumulating that with EBV treatment real personalized medicine for the treatment of patients with severe emphysema is possible, with even as high as a $75 \%$ responder rate to treatment when using a combined approach for recruiting potential candidates: assessment of fissure integrity to 
Table 3. Summary of trial design, number of patients, follow-up duration and the main efficacy parameters (FEV $1, \mathrm{RV}, 6 \mathrm{MWT}$ distance and SGRQ) for the endoscopic lung volume reduction trials published

\begin{tabular}{|c|c|c|c|c|c|c|c|}
\hline $\begin{array}{l}\text { Device/first } \\
\text { author, year [Ref.] }\end{array}$ & Trial design & $\begin{array}{l}\text { Patients } \\
\text { treated, } \mathrm{n}\end{array}$ & $\begin{array}{l}\text { Follow-up } \\
\text { duration }\end{array}$ & $\Delta \mathrm{FEV}_{1}$ & $\Delta \mathrm{RV}$ & $\Delta 6 \mathrm{MWT}$ distance & $\begin{array}{l}\triangle \mathrm{SGRQ} \text {, total } \\
\text { score }\end{array}$ \\
\hline \multicolumn{8}{|l|}{$E B V$} \\
\hline \multirow[t]{2}{*}{ Park, 2015 [53] } & $\begin{array}{l}\text { Prospective open-label } \\
\text { single-arm trial }\end{array}$ & 43 & $\begin{array}{l}3 \text { months } \\
(\mathrm{n}=35)\end{array}$ & $\begin{array}{l}0.68 \pm 0.26 \\
\text { to } 0.89 \pm 0.37 \\
\text { liters }\end{array}$ & $\begin{array}{l}4.98 \pm 1.15 \\
\text { to } 3.91 \pm 1.15 \text { liters }\end{array}$ & $\begin{array}{l}233.5 \pm 114.8 \text { to } \\
283.7 \pm 121.6 \mathrm{~m}\end{array}$ & $\begin{array}{l}65.59 \pm 13.07 \text { to } \\
55.70 \pm 13.79\end{array}$ \\
\hline & Single center & & $\begin{array}{l}6 \text { months } \\
(\mathrm{n}=27)\end{array}$ & $\begin{array}{l}0.68 \pm 0.26 \\
\text { to } 0.92 \pm 0.40 \\
\text { liters }\end{array}$ & $\begin{array}{l}4.98 \pm 1.15 \\
\text { to } 3.67 \pm 0.95 \text { liters }\end{array}$ & $\begin{array}{l}233.5 \pm 114.8 \text { to } \\
299.6 \pm 87.5 \mathrm{~m}\end{array}$ & $\begin{array}{l}65.59 \pm 13.07 \text { to } \\
53.76 \pm 11.40\end{array}$ \\
\hline Herth, 2013 [29] & $\begin{array}{l}\text { Nonrandomized } \\
\text { prospective trial } \\
\text { Multicenter }\end{array}$ & $\begin{array}{l}51(\mathrm{CV} \text { negative } \\
\text { patients) }\end{array}$ & 30 days & $\begin{array}{l}0.14 \pm 0.20 \text { liters } \\
16 \pm 22 \%\end{array}$ & $4.49 \pm 1.22$ & $24 \pm 57$ & $-10 \pm 13$ \\
\hline Sciurba, $2010[22]$ & Prospective RCT & 220 & 6 months & $\begin{array}{l}4.3 \% \text { (95\% CI: } \\
1.4-7.2) \\
34.5 \mathrm{ml} \\
(10.8-58.3)\end{array}$ & & $\begin{array}{l}2.5 \%(95 \% \mathrm{CI}: \\
-1.1 \text { to } 6.1) \\
9.3 \mathrm{~m}(95 \% \mathrm{CI} \text { : } \\
-0.5 \text { to } 19.1)\end{array}$ & $\begin{array}{l}-2.8 \\
(-4.7 \text { to }-1.0)\end{array}$ \\
\hline
\end{tabular}

\section{IBV}

Szlubowska, 2015 Prospective observational20 3 months

$-12.8 \pm 11.9$

[54]

study

Single center

\begin{tabular}{|c|c|c|c|c|c|c|c|}
\hline Ninane, 2012 [24] & $\begin{array}{l}\text { Single-blinded sham- } \\
\text { controlled RCT } \\
\text { Multicenter }\end{array}$ & 37 & $\begin{array}{l}3 \text { months } \\
6 \text { months }\end{array}$ & $\begin{array}{l}0.99 \pm 0.35 \text { to } \\
0.90 \pm 0.34 \text { liters }\end{array}$ & $\begin{array}{l}4.65 \pm 1.30 \text { to } \\
4.86 \pm 1.35 \text { liters }\end{array}$ & $\begin{array}{l}337 \pm 106 \text { to } \\
344 \pm 18 \mathrm{~m}\end{array}$ & $\begin{array}{l}-4.3 \pm 16.2 \\
-10.9 \pm 18.2\end{array}$ \\
\hline $\begin{array}{l}\text { Eberhardt, } 2012 \\
{[36]}\end{array}$ & $\begin{array}{l}\text { RCT } \\
\text { Single center }\end{array}$ & $\begin{array}{l}11 \text { (unilateral) } \\
11 \text { (bilateral) }\end{array}$ & $\begin{array}{l}30 \text { days } \\
30 \text { days }\end{array}$ & $\begin{array}{l}267 \pm 154 \mathrm{ml} \\
13 \pm 140 \mathrm{ml}\end{array}$ & $\begin{array}{l}-546 \pm 1307 \mathrm{ml} \\
61 \pm 990 \mathrm{ml}\end{array}$ & $\begin{array}{l}47.8 \pm 55.7 \mathrm{~m} \\
-25.0 \pm 81.5 \mathrm{~m}\end{array}$ & $\begin{array}{l}-12.2 \pm 13.4 \\
-0.3 \pm 9.8\end{array}$ \\
\hline Sterman, 2010 [55] & $\begin{array}{l}\text { Prospective, open } \\
\text { enrollment, consecutive } \\
\text { case series }\end{array}$ & 91 & 6 months & $\begin{array}{l}0.87 \pm 0.25 \text { to } \\
0.83 \pm 0.29\end{array}$ & $\begin{array}{l}4.74 \pm 1.06 \text { to } \\
4.89 \pm 1.17\end{array}$ & $\begin{array}{l}338 \pm 95 \text { to } \\
351 \pm 102\end{array}$ & $-8.2 \pm 16.2$ \\
\hline & Multicenter & & 12 months & $\begin{array}{l}0.87 \pm 0.25 \text { to } \\
0.85 \pm 0.33\end{array}$ & $\begin{array}{l}4.74 \pm 1.06 \text { to } \\
4.71 \pm 1.27\end{array}$ & $\begin{array}{l}338 \pm 95 \text { to } \\
358 \pm 92\end{array}$ & $-9.5 \pm 14.4$ \\
\hline Coil & & & & & & & \\
\hline Gulsen, 2015 [56] & $\begin{array}{l}\text { Retrospective analysis } \\
\text { Single center }\end{array}$ & 40 & 6 months & $\begin{array}{l}+0.15 \text { liters } \\
(+24.7 \%)\end{array}$ & $\begin{array}{l}-0.82 \text { liters } \\
(-14.5 \%)\end{array}$ & $+48 \mathrm{~m}$ & -10.4 \\
\hline Deslee, 2015 [41] & $\begin{array}{l}\text { Prospective randomized } \\
\text { controlled superiority } \\
\text { trial } \\
\text { Multicenter }\end{array}$ & 50 & 1 year & & & $\begin{array}{l}36 \% \text { improver } \\
\geq 54 \mathrm{~m}\end{array}$ & \\
\hline $\begin{array}{l}\text { Kontogianni, } 2014 \\
\text { [57] }\end{array}$ & $\begin{array}{l}\text { Retrospective analysis } \\
\text { Single center }\end{array}$ & 26 & $\begin{array}{l}90 \text { days } \\
180 \text { days }\end{array}$ & $\begin{array}{l}0.10 \pm 0.13 \text { liters } \\
0.04 \pm 0.12 \text { liters }\end{array}$ & $\begin{array}{l}-0.6 \text { liters } \\
-0.42 \text { liters }\end{array}$ & $\begin{array}{l}47 \pm 54 \mathrm{~m} \\
32 \pm 60 \mathrm{~m}\end{array}$ & $\begin{array}{l}-7 \\
-6 \\
\end{array}$ \\
\hline Klooster, 2014 [42] & $\begin{array}{l}\text { Prospective, open-label, } \\
\text { cohort trial } \\
\text { Single center }\end{array}$ & 10 & 3-4 months & $\begin{array}{l}16.6 \% \\
(-16 \text { to } 55)\end{array}$ & $\begin{array}{l}-0.79 \text { liters } \\
(-1.20 \text { to } 0.04)\end{array}$ & $\begin{array}{l}42 \mathrm{~m} \\
(15 \pm 141)\end{array}$ & $-11(-25 \pm 6)$ \\
\hline Deslee, 2014 [43] & $\begin{array}{l}\text { Prospective open-label } \\
\text { feasibility study } \\
\text { Multicenter }\end{array}$ & 60 & $\begin{array}{l}6 \text { months } \\
12 \text { months }\end{array}$ & $\begin{array}{l}15.4 \pm 26.7 \% \\
16.0 \pm 35.5 \%\end{array}$ & $\begin{array}{l}-11.3 \pm 15.3 \% \\
-13.8 \pm 12.7 \%\end{array}$ & $\begin{array}{l}29.7 \pm 74.1 \mathrm{~m} \\
51.4 \pm 76.1 \mathrm{~m}\end{array}$ & $\begin{array}{l}-12.1 \pm 12.9 \\
-11.1 \pm 13.3\end{array}$ \\
\hline Shah, 2013 [40] & $\begin{array}{l}\text { Prospective RCT } \\
\text { Multicenter }\end{array}$ & 23 & 90 days & $\begin{array}{l}14.2 \% \\
(6.8-21.6)\end{array}$ & $\begin{array}{l}-0.51 \text { liters } \\
(-0.73 \text { to }-0.30)\end{array}$ & $\begin{array}{l}51.2 \mathrm{~m} \\
(27.7-74.7)\end{array}$ & $\begin{array}{l}-8.1 \\
(-13.8 \text { to } 2.4)\end{array}$ \\
\hline$\overline{\text { Slebos, } 2012 \text { [39] }}$ & $\begin{array}{l}\text { Prospective cohort pilot } \\
\text { study } \\
\text { Single center }\end{array}$ & 16 & $\begin{array}{l}3 \text { months } \\
6 \text { months }\end{array}$ & $\begin{array}{l}19.9 \pm 20.0 \% \\
14.9 \pm 17 \%\end{array}$ & $\begin{array}{l}-11.1 \pm 9.9 \% \\
-11.4 \pm 9 \%\end{array}$ & $\begin{array}{l}62.2 \pm 76.6 \mathrm{~m} \\
84.4 \pm 73.4 \mathrm{~m}\end{array}$ & $\begin{array}{l}-12.6 \pm 10.8 \\
-14.9 \pm 12.1\end{array}$ \\
\hline
\end{tabular}


Table 3 (continued)

\begin{tabular}{|c|c|c|c|c|c|c|c|}
\hline $\begin{array}{l}\text { Device/first } \\
\text { author, year [Ref.] }\end{array}$ & Trial design & $\begin{array}{l}\text { Patients } \\
\text { treated, } \mathrm{n}\end{array}$ & $\begin{array}{l}\text { Follow-up } \\
\text { duration }\end{array}$ & $\Delta \mathrm{FEV}_{1}$ & $\Delta \mathrm{RV}$ & $\Delta 6 \mathrm{MWT}$ distance & $\begin{array}{l}\triangle \text { SGRQ, total } \\
\text { score }\end{array}$ \\
\hline \multicolumn{8}{|l|}{ Vapor } \\
\hline Herth, 2016 [58] & $\begin{array}{l}\text { RCT } \\
\text { Multicenter }\end{array}$ & 44 & 6 months & \multicolumn{2}{|l|}{$+13.1 \%$ predicted } & $+31 \mathrm{~m}$ & -11.1 \\
\hline \multirow[t]{2}{*}{ Herth, 2012 [45] } & $\begin{array}{l}\text { Two open-label, single- } \\
\text { arm studies }\end{array}$ & 44 & 6 months & $141 \pm 166 \mathrm{ml}$ & $-406 \pm 714 \mathrm{ml}$ & $46.5 \pm 67.1 \mathrm{~m}$ & $-14.0 \pm 15.1$ \\
\hline & Multicenter & & 12 months & $86 \pm 174 \mathrm{ml}$ & $-303 \pm 776 \mathrm{ml}$ & $18.5 \pm 63.7 \mathrm{~m}$ & $-11.0 \pm 14.0$ \\
\hline Snell, 2012 [44] & Pilot study & 11 & 6 months & $\begin{array}{l}0.77-0.79 \\
(0.49-1.18)\end{array}$ & $\begin{array}{l}4.16(4.00-5.85) \text { to } \\
4.13(2.99-5.77)\end{array}$ & $\begin{array}{l}359(233-495) \text { to } \\
362(210-527)\end{array}$ & $\begin{array}{l}64.4(37-84) \text { to } \\
49.1(32-64)\end{array}$ \\
\hline \multicolumn{8}{|l|}{ AeriSeal } \\
\hline \multirow[t]{2}{*}{ Come, 2015 [51] } & $\mathrm{RCT}$ & 59 & $\begin{array}{l}3 \text { months } \\
(\mathrm{n}=34)\end{array}$ & $\begin{array}{l}110 \mathrm{ml} \\
(18-211 \mathrm{ml})\end{array}$ & & not collected & $\begin{array}{l}-11 \\
(-18 \text { to }-1)\end{array}$ \\
\hline & Multicenter & & $\begin{array}{l}6 \text { months } \\
(\mathrm{n}=21)\end{array}$ & $\begin{array}{l}100 \mathrm{ml} \\
(0-370 \mathrm{ml})\end{array}$ & & $31.0 \mathrm{~m}(0-41.3 \mathrm{~m})$ & $\begin{array}{l}-12 \\
(-22 \text { to }-5)\end{array}$ \\
\hline \multirow[t]{2}{*}{ Kramer, 2012 [50] } & $\begin{array}{l}\text { Single-arm, prospective } \\
\text { study }\end{array}$ & 20 & 6 months & $335 \pm 438 \mathrm{ml}$ & $-485 \pm 981 \mathrm{ml}$ & $11.8 \pm 57.5 \mathrm{~m}$ & $-8.0 \pm 17.2$ \\
\hline & Multicenter & & 12 months & $278 \pm 425 \mathrm{ml}$ & $-864 \pm 948 \mathrm{ml}$ & $8.6 \pm 65.2 \mathrm{~m}$ & $-7.0 \pm 15.8$ \\
\hline \multirow[t]{2}{*}{ Herth, 2011 [49] } & $\begin{array}{l}\text { Pilot study, } \\
\text { noncontrolled, open- } \\
\text { label }\end{array}$ & 21 & 21 weeks & $\begin{array}{l}0.070 \pm 0.193 \\
\text { liters }\end{array}$ & & $35.6 \pm 66.7 \mathrm{~m}$ & $-7.1 \pm 14.2$ \\
\hline & Multicenter & & 24 weeks & $\begin{array}{l}0.105 \pm 0.201 \\
\text { liters }\end{array}$ & & $24.6 \pm 58.9 \mathrm{~m}$ & $-7.5 \pm 14.4$ \\
\hline
\end{tabular}

preselect patients, and confirm absence of collateral flow with Chartis.

The major complications after a valve placement are COPD exacerbations, hemoptysis, valve migration, and pneumothorax. Since the introduction of fissure analysis and Chartis measurement of collateral ventilation for patient selection, there has been a steady increase in the incidence of pneumothoraces, which has been estimated at $20 \%$ in the latest series [31]. Providing patients receive prompt treatment, those who experience a pneumothorax have a greater clinical response, and in these cases pneumothorax may even be considered as a predictor of success [32].

Nevertheless, a pneumothorax is a serious complication and therefore strict monitoring of patients within the first 72-96 h following intervention is crucial, as pneumothorax develops most often directly after treatment to within the first 4 days. An expert statement regarding the handling of pneumothorax has already been published [33].

The EBVs have now been used for more than 10 years, and 2 small long-term series have been published on these valves, the only removable endoscopic lung volume reduction technique at the moment. Both series showed a significant survival benefit in the successfully treated compared to the unsuccessfully treated group $[34,35]$.
Several trials using the EBVs are currently ongoing focusing on the optimal patient selection in patients with absence of collateral ventilation (LIBERATE trial, NCT01796392, and TRANSFORM trial, NCT02022683), long-term follow-up (LIVE study, NCT01580215), evaluation of outcomes of valve therapy in patients with more moderate COPD (REMODEL trial, NCT01969734) or in patients with a homogenous emphysema distribution (IMPACT trial, NCT02025205).

Although the IBV (Olympus) is commercially available, and has been investigated intensively, only one published small $(n=11)$ trial has shown efficacy [36]. The previously reported intended use of this device, i.e. in a nonlobar occluding bilateral approach, was not clinically effective, and has been abandoned [24, 36].

Coils

Lung volume reduction with coils (PneumRx/BTG, Camberley, UK) is a bronchoscopic bilateral implantation technique of several nitinol coils. The lung volume reduction is achieved by parenchymal compression due to the preformed coiled shape. Improved elastic recoil and changes in compliance as well as reduction of trapped airspace are possible mechanisms of actions [37].

First reports have demonstrated feasibility and safety of the procedure with encouraging results $[38,39]$. The 
RESET trial provided the randomized controlled evidence for this technology. Forty-seven patients were assigned 1:1 to the treatment or control group, and all treated patients received a bilateral coil implantation [40]. The trial showed statistically and clinically significant improvement in lung function [6MWT and St George's Respiratory Questionnaire (SGRQ): 8.11 vs. 0.25 points]. A multicenter European prospective single-arm trial on 60 patients confirmed the efficacy and demonstrated that the benefits were sustained for up to 1 year after treatment [41]. In a small series, it was suggested that coil implantation might also be an effective approach for patients with homogeneous emphysema [42].

The reported complications of the coil procedure are COPD exacerbations, hemoptysis, transient chest pain, pneumonia, and pneumothorax [37]. Most of the complications occurred in the first weeks following placement, and only mild hemoptysis was seen over time.

Two randomized controlled trials have recently been completed. A multicenter trial from France $(\mathrm{n}=100)$ (NCT01822795) [43] has just reported its first results in abstract form showing in their intention-to-treat analysis the superiority of the LVRC group in the number of patients exceeding $\geq 54 \mathrm{~m}$ in the $6 \mathrm{MWT}$ at 6 months compared to the standard of care control group (36 vs. $17 \%$ of the patients, $p<0.05)$. A much larger RCT called the RENEW trial (NCT01608490), with 315 patients randomized 1:1 in over 30 centers in the US, Canada, and EU, has just been completed, with the first results expected in mid2016. In this trial, the questions regarding preimplant selection criteria should be answered, in addition to evaluating the safety of the coil implant, as well as its effects on lung function, exercise capacity and quality of life.

\section{Bronchoscopic Thermal Vapor Ablation}

Bronchoscopic thermal vapor ablation (BTVA; Uptake Medical Corporation, Seattle, Wash., USA) consists of the instillation of heated water in the most destroyed lobe. Thereby, an inflammatory response is induced, which results in an irreversible parenchymal fibrosis and scarring and thus lung volume reduction.

The evidence level for BTVA is limited. In a subsequent multicenter single-arm trial, 44 patients with upper lobe predominant emphysema were studied [44]. The trial was able to show significant changes in $\mathrm{FEV}_{1}$, vital capacity, 6MWT and SGRQ. A 12-month follow-up confirmed the sustainability of lobar volume changes [45]. However, despite the promising results in these first trials, a high number of serious adverse events occurred, possibly due to a cumulative high-energy dose used, and the approach had to be abandoned. The most common complication of BTVA was due to the induced inflammation. Most patients developed a severe local inflammatory reaction, associated with fever, cough, sputum, dyspnea, and hemoptysis. Most of the inflammatory reactions gradually resolve within 8-12 weeks after the procedure. Nevertheless, the inflammatory response can lead to a prolonged hospital stay. However, the local inflammatory reaction seems to be essential for the desired lobar volume reduction. Patients who developed respiratory adverse events following BTVA experienced a better clinical outcome [46].

Recently, the initial results of a randomized controlled multicenter trial (STEP-UP trial, NCT01719263) were presented in abstract form [47]. In this trial, much lower BTVA energy doses have been used, still showing significant results for $\mathrm{FEV}_{1}$ and SGRQ, but with a safer event profile when compared to the previous BTVA efforts. Future trials, with longer-term follow-up, will have to confirm these early findings.

\section{Biological Lung Volume Reduction}

Biological lung volume reduction using the lung sealant system (AeriSeal) is another irreversible endoscopic lung volume reduction technique that employs a synthetic polymer to block small airways and collateral channels, promoting atelectasis, remodeling, and scar formation. This results in a reduction of hyperinflation. The technique is independent of collateral ventilation [48]. In open-label pilot studies, the sealant system durably reduced lung volume and improved lung function as well as quality of life, which was more pronounced in heterogeneous emphysema when compared to homogeneous emphysema patients $[49,50]$. The most common side effects are comparable to the vapor technology.

Based on these feasibility results, an open-label, prospective, multicenter RCT in patients with advanced, upper lobe predominant emphysema was started (ASPIRE trial, NCT01449292). The study was terminated prematurely for business-related reasons after 95 out of 300 planned patients had been randomized. In the treatment group, the 3-month lung function, dyspnea, and quality of life improved significantly from baseline when compared to controls. Improvements persisted at 6 months with $>50 \%$ of treated patients experiencing clinically important improvements; $44 \%$ of treated patients experienced adverse events requiring hospitalization with 2 deaths in the treated cohort. Treatment responders tended to be those experiencing respiratory adverse events [51]. This technology is currently undergoing further evaluation prior to further clinical trials. 


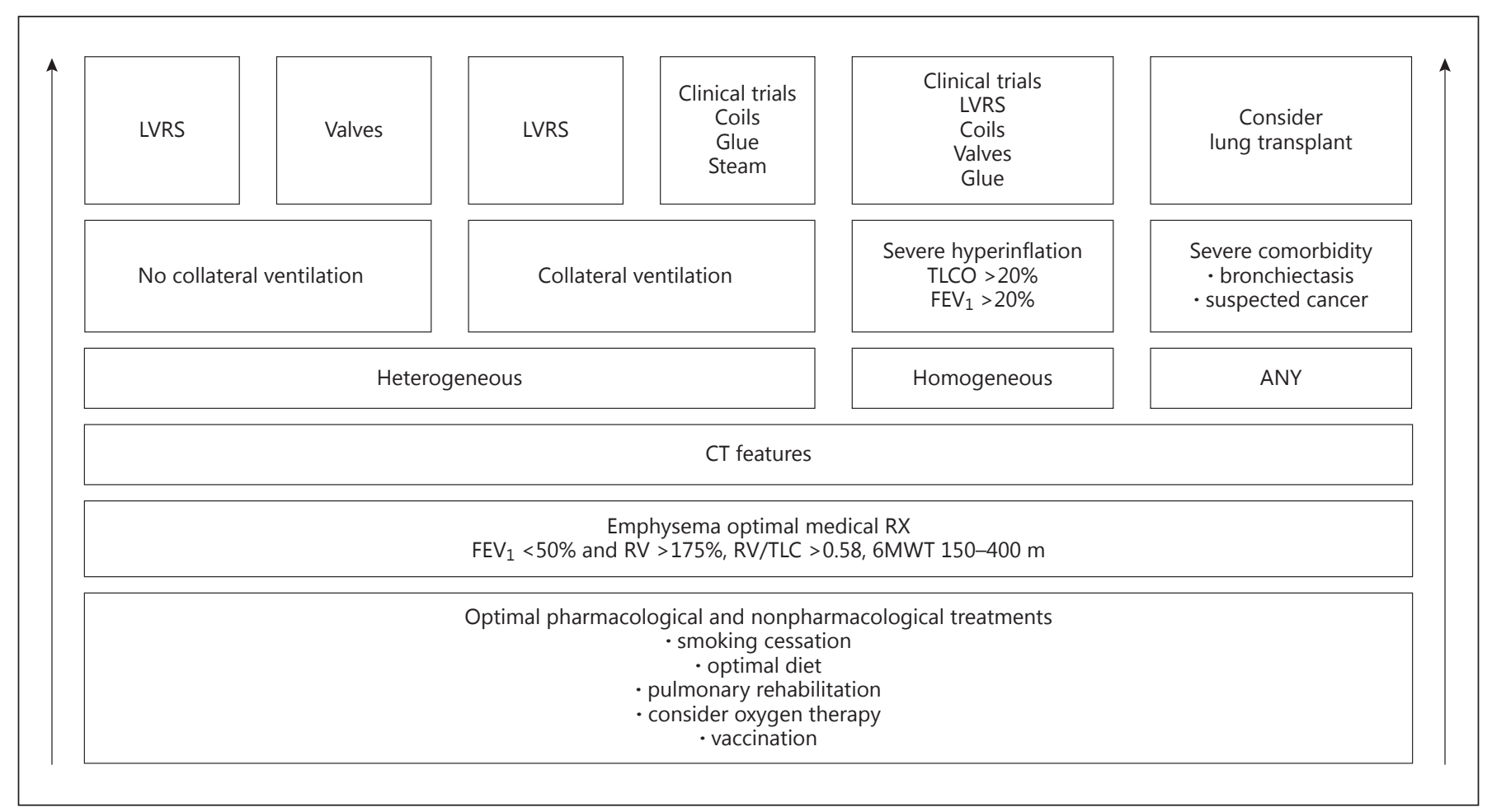

Fig. 1. Algorithm for the advanced treatment of severe emphysema patients.

\section{Expert Algorithm}

In a round table discussion starting at the end of 2014, an expert endoscopic panel developed the presented algorithm for the advanced treatment of severe emphysema patients, based on the above-presented literature (fig. 1). All emphysema patients considered should be on optimal pharmacological and nonpharmacological treatment in agreement with the actual GOLD recommendations or the national guidelines [1]. According to the panel members, active smoking is a clear contraindication.

Patients fulfilling these criteria should have a significant hyperinflation measured in the lung by body plethysmography. In the performed CT scan, other relative findings must be reported and might be the reason to stop further evaluation.

All qualified patients should be discussed by a multidisciplinary team including radiologists, pulmonologists, thoracic surgeons as well as an interventional pulmonologist.

For all patients, lung transplantation might be an option, and connection or easy access to a program is recommended. Therefore, this possibility should be consid- ered as well. The transplant option is not a contraindication for endoscopic lung volume reduction [52]. It can therefore be elegantly used also as a bridging method.

Depending on the heterogeneity of the emphysema and the collateral flow, analyzed by the completeness of the fissure and confirmed with the Chartis system, the algorithm shown in figure 1 recommends the further options. Only LVRS and the EBV reached the evidence level to be used outside of clinical trials. However, both are recommended to still be used in registries.

Current endoscopic developments are significantly progressing as mentioned above, and will for sure add more input to the current algorithm. LVRS is still a valid treatment option; however, nowadays new surgical techniques are available and even more often used than the ones evaluated in NETT, thereby questioning the current validity of the NETT results. The new techniques look solid and promising in creative hands, but the science behind these developments is currently lacking. The evidence for endobronchial therapies is accumulating and the latter represent a viable alternative in selected patients. 


\section{References}

1 Vestbo J, et al: Global strategy for the diagnosis, management, and prevention of chronic obstructive pulmonary disease: GOLD executive summary. Am J Respir Crit Care Med 2013;187:347-365.

-2 Kemp SV, Polkey MI, Shah PL: The epidemiology, etiology, clinical features, and natural history of emphysema. Thorac Surg Clin 2009; 19:149-158.

-3 Klooster K, et al: Determining the role of dynamic hyperinflation in patients with severe chronic obstructive pulmonary disease. Respiration 2015;90:306-313.

$\checkmark 4$ Jordan RE, et al: Case finding for chronic obstructive pulmonary disease: a model for optimising a targeted approach. Thorax 2010; 65:492-498.

$>5$ Halbert RJ, et al: Global burden of COPD: systematic review and meta-analysis. Eur Respir J 2006;28:523-532.

6 Bloom DE, Cafiero ET, Jané-Llopis E, Abrahams-Gessel S, Bloom LR, Fathima S, Feigl AB, Gaziano T, Mowafi M, Pandya A, Prettner K, Rosenberg L, Seligman B, Stein AZ, Weinstein C: The global economic burden of noncommunicable diseases. World Economic Forum, 2011. http://www.weforum.org/EconomicsOfNCD.

7 Qaseem A, et al: Diagnosis and management of stable chronic obstructive pulmonary disease: a clinical practice guideline update from the American College of Physicians, American College of Chest Physicians, American Thoracic Society, and European Respiratory Society. Ann Intern Med 2011;155:179-191.

$>8$ Cooper CB: The connection between chronic obstructive pulmonary disease symptoms and hyperinflation and its impact on exercise and function. Am J Med 2006;119(suppl 1):21-31.

>9 Brantigan OC, Mueller E: Surgical treatment of pulmonary emphysema. Am Surg 1957;23: 789-804.

10 Marchetti N, Criner GJ: Surgical approaches to treating emphysema: lung volume reduction surgery, bullectomy, and lung transplantation. Semin Respir Crit Care Med 2015;36: 592-608.

11 Beckers F, et al: Unilateral lobe resection by video-assisted thoracoscopy leads to the most optimal functional improvement in severe emphysema. Thorac Cardiovasc Surg 2014, Epub ahead of print.

$\checkmark 12$ Pompeo E, et al: Randomized comparison of awake nonresectional versus nonawake resectional lung volume reduction surgery. J Thorac Cardiovasc Surg 2012;143:47-54, 54 e1.

13 Criner GJ, et al: The National Emphysema Treatment Trial (NETT). II. Lessons learned about lung volume reduction surgery. Am J Respir Crit Care Med 2011;184:881-893.

$>14$ Van Raemdonck D, Ninane V: Lung volume reduction for severe emphysema: do we need a scalpel or a scope? Eur Respir Rev 2010;19: 242-247.
15 Lynch DA, Newell JD: Quantitative imaging of COPD. J Thorac Imaging 2009;24:189194.

16 Muller NL, et al: 'Density mask'. An objective method to quantitate emphysema using computed tomography. Chest 1988;94:782-787.

17 Mets OM, et al: Quantitative computed tomography in COPD: possibilities and limitations. Lung 2012;190:133-145.

18 Gevenois PA, et al: Comparison of computed density and macroscopic morphometry in pulmonary emphysema. Am J Respir Crit Care Med 1995;152:653-657.

19 Gevenois PA, et al: Comparison of computed density and microscopic morphometry in pulmonary emphysema. Am J Respir Crit Care Med 1996;154:187-192.

20 Koenigkam-Santos M, et al: Incomplete fissures in severe emphysematous patients evaluated with MDCT: incidence and interobserver agreement among radiologists and pneumologists. Eur J Radiol 2012;81:41614166.

21 Toma TP, et al: Bronchoscopic volume reduction with valve implants in patients with severe emphysema. Lancet 2003;361:931-933.

22 Sciurba FC, et al: A randomized study of endobronchial valves for advanced emphysema. N Engl J Med 2010;363:1233-1244.

23 Herth FJ, et al: Efficacy predictors of lung volume reduction with Zephyr valves in a European cohort. Eur Respir J 2012;39:1334-1342.

24 Ninane V, et al: Multicentre European study for the treatment of advanced emphysema with bronchial valves. Eur Respir J 2012;39: 1319-1325.

25 Valipour A, et al: Target lobe volume reduction and COPD outcome measures after endobronchial valve therapy. Eur Respir J 2014; 43:387-396.

26 Davey C, et al: Bronchoscopic lung volume reduction with endobronchial valves for patients with heterogeneous emphysema and intact interlobar fissures (the BeLieVeR-HIFi study): a randomised controlled trial. Lancet 2015;386:1066-1073.

27 Schuhmann M, et al: Computed tomography predictors of response to endobronchial valve lung reduction treatment. Comparison with Chartis. Am J Respir Crit Care Med 2015;191: 767-774.

28 Gompelmann D, et al: Predicting atelectasis by assessment of collateral ventilation prior to endobronchial lung volume reduction: a feasibility study. Respiration 2010;80:419-425.

29 Herth FJ, et al: Radiological and clinical outcomes of using Chartis to plan endobronchial valve treatment. Eur Respir J 2013;41:302308.

30 Klooster K: Endobronchial valve treatment versus standard medical care in patients with emphysema without interlobar collateral ventilation (The STELVIO-Trial). Am J Respir Crit Care Med 2015;191:A6312.
31 Gompelmann D, Eberhardt R, Herth F: Endoscopic volume reduction in COPD - a critical review. Dtsch Arztebl Int 2014;111:827-833.

32 Gompelmann D, et al: Pneumothorax following endobronchial valve therapy and its impact on clinical outcomes in severe emphysema. Respiration 2014;87:485-491.

33 Valipour A, et al: Expert statement: pneumothorax associated with endoscopic valve therapy for emphysema - potential mechanisms, treatment algorithm, and case examples. Respiration 2014;87:513-521.

34 Venuta F, et al: Long-term follow-up after bronchoscopic lung volume reduction in patients with emphysema. Eur Respir J 2012;39: 1084-1089.

35 Hopkinson NS, et al: Atelectasis and survival after bronchoscopic lung volume reduction for COPD. Eur Respir J 2011;37:1346-1351.

36 Eberhardt R, et al: Complete unilateral vs partial bilateral endoscopic lung volume reduction in patients with bilateral lung emphysema. Chest 2012;142:900-908.

37 Klooster K, Ten Hacken NH, Slebos DJ: The lung volume reduction coil for the treatment of emphysema: a new therapy in development. Expert Rev Med Devices 2014;11:481489.

38 Herth FJ, et al: Bronchoscopic lung volume reduction with a dedicated coil: a clinical pilot study. Ther Adv Respir Dis 2010;4:225-231.

39 Slebos DJ, et al: Bronchoscopic lung volume reduction coil treatment of patients with severe heterogeneous emphysema. Chest 2012; 142:574-582.

40 Shah PL, et al: Endobronchial coils for the treatment of severe emphysema with hyperinflation (RESET): a randomised controlled trial. Lancet Respir Med 2013;1:233-240.

41 Deslee $G$, et al: Lung volume reduction coil treatment for patients with severe emphysema: a European multicentre trial. Thorax 2014;69:980-986.

42 Klooster K, et al: Lung volume reduction coil treatment in chronic obstructive pulmonary disease patients with homogeneous emphysema: a prospective feasibility trial. Respiration 2014;88:116-125.

43 Deslee G: Lung volume reduction coil treatment improves exercise capacity at 6 months in severe emphysema: preliminary results of the randomized control trial REVOLENS. Am J Respir Crit Care Med 2015;191:A6364.

44 Snell G, et al: Bronchoscopic thermal vapour ablation therapy in the management of heterogeneous emphysema. Eur Respir J 2012; 39:1326-1333.

45 Herth FJ, et al: Characterization of outcomes 1 year after endoscopic thermal vapor ablation for patients with heterogeneous emphysema. Int J Chron Obstruct Pulmon Dis 2012; 7:397-405.

46 Gompelmann D, et al: The localized inflammatory response to bronchoscopic thermal vapor ablation. Respiration 2013;86:324-331. 
47 Bandyopadhyay S, et al: Segmental approach to lung volume reduction therapy for emphysema patients. Respiration 2015;89:76-81.

48 Magnussen $\mathrm{H}$, et al: Effect of fissure integrity on lung volume reduction using a polymer sealant in advanced emphysema. Thorax 2012;67:302-308.

49 Herth FJ, et al: Treatment of advanced emphysema with emphysematous lung sealant (AeriSeal ${ }^{\circledR}$ ). Respiration 2011;82:36-45.

50 Kramer MR, et al: Bilateral endoscopic sealant lung volume reduction therapy for advanced emphysema. Chest 2012;142:1111-1117.

51 Come CE, et al: A randomised trial of lung sealant versus medical therapy for advanced emphysema. Eur Respir J 2015;46:651-662.

52 Fuehner T, et al: Lung transplantation after endoscopic lung volume reduction. Respiration 2015;90:243-250.
53 Park TS, Hong Y, Lee JS, Oh SY, Lee SM, Kim $\mathrm{N}$, Seo JB, Oh YM, Lee SD, Lee SW: Bronchoscopic lung volume reduction by endobronchial valve in advanced emphysema: the first Asian report. Int J Chron Obstruct Pulmon Dis 2015;10:1501-1511.

54 Szlubowska S, Zalewska-Puchała J, Majda A, Kocoń P, Soja J, Gnass M1, Pasko E, Ćmiel A, Szlubowski A, Kużdżał J: The influence of lung volume reduction with intrabronchial valves on the quality of life of patients with heterogeneous emphysema - a prospective study. Pneumonol Alergol Pol 2015;83:418423.

5 Sterman DH, Mehta AC, Wood DE, Mathur PN, McKenna RJ Jr, Ost DE, Truwit JD, Diaz P, Wahidi MM, Cerfolio R, Maxfield R, Musani AI, Gildea T, Sheski F, Machuzak M, Haas AR, Gonzalez HX, Springmeyer SC; IBV Valve US Pilot Trial Research Team: A multicenter pilot study of a bronchial valve for the treatment of severe emphysema. Respiration 2010;79:222-233
56 Gulsen A, Sever F, Girgin P, Tamci NB, Yilmaz $\mathrm{H}$ : Evaluation of bronchoscopic lung volume reduction coil treatment results in patients with severe emphysema. Clin Respir J 2015, Epub ahead of print.

57 Kontogianni K, Gerovasili V, Gompelmann D, Schuhmann M, Heussel CP, Herth FJ, Eberhardt R: Effectiveness of endobronchial coil treatment for lung volume reduction in patients with severe heterogeneous emphysema and bilateral incomplete fissures: a six-month follow-up. Respiration 2014;88:52-60.

58 Herth FJF, Valipour A, Shah P, et al: STEP-UP randomized controlled trial of segmental vapor ablation in patients with severe emphysema: month results. Lancet Respir Med 2016, accepted. 